\title{
CO NAM DZIŚ PO HEREZJI?
}

\author{
Michał Rogalski
}

Po co pisać o herezji? Czy pojęcie ze słownika teologii chrześcijańskiej i prawa kościelnego może stanowić punkt wyjścia dla współczesnej refleksji humanistycznej? Niemal czterdzieści lat temu Leszek Kołakowski, podejmując to zagadnienie w cyklu wykładów na antenie Radia Wolna Europa (1982-1983), zdawał sprawę z podobnych wahań: „Mogłoby się wydawać, że herezje to nie jest temat szczególnie naglący w obecnej polskiej sytuacji. Po pierwsze jednak, nawet w najgorszych czasach, w najgorszych okolicznościach, wolno albo wręcz trzeba myśleć o sprawach nie wprost z nasza sytuacją związanych" (Kołakowski 2010: 7). Wahanie zostaje tu natychmiast zdekonstruowane. Autor stwierdza, że kontekst sytuacji politycznej i społecznej (był to czas po krachu karnawału solidarnościowego i smuta stanu wojennego) nie może ograniczać i zawężać horyzontu badań humanistycznych. W kolejnych zdaniach zaś przekonuje, że z pozoru dalekie od aktualności tematy prezentują uniwersalne i użyteczne problematy myślowe. W przypadku herezji takim uniwersalnym wątkiem ma być sytuacja konfliktu postaw ideowych, religijnych i społecznych.

Wyjaśnienia Kołakowskiego można uznać za adekwatne na antenie radia, którego głównym zadaniem było przekraczanie ograniczeń autorytarnej cenzury i rozbijanie monopolu władzy na opis i interpretację rzeczywistości. Numer czasopisma naukowego z obszaru nauk społecznych to zupełnie inny kontekst dla pytania „po co pisać o herezji?”.

Naszym zamiarem była praca nad pojęciem i zjawiskiem herezji, a nie potraktowanie jej jako modelu innego zjawiska. Zainteresowało nas dialektyczne napięcie kryjące się już w greckim źródłosłowie. Hairesis to tyle co „wybór” lub „rzecz wybrana”. Terminem tym określano wewnętrzne napięcia i konflikty we wczesnochrześcijańskiej wspólnocie (Gal 5,20; 
1 Kor 11,18n) albo też wprost błędne nauczanie - a więc „odstępstwa” (2 P 2,1; Tyt 3,10). Ten drugi obszar semantyczny naznaczony jest już negatywnymi konotacjami, które kościoły chrześcijańskie dość szybko przydały ideowym i duchowym „wyborom”, by w końcu uznać herezje, a przede wszystkim samych heretyków za grożących jedności wspólnoty. Wyznawcy wyboru okazali się wyznawcami błędu, czym zasłużyli na doczesne i wieczne sankcje prawne. Nie przypadkiem doktrynalne podsumowania (kanony) pierwszych soborów niepodzielonego jeszcze na wschodni i zachodni kościoła wiążą się z deklaracjami wyłączenia ze wspólnoty wszystkich inaczej myślących. Fragment orzeczenia soboru chalcedońskiego z 451 roku będzie tu reprezentatywnym przykładem: „Co się tyczy tych, którzy ośmielają się inną Wiarę układać bądź nauczać i głosić albo przekazywać inny symbol pragnącym z pogaństwa, judaizmu czy jakiejkolwiek innej herezji nawrócić się ku prawdziwemu poznaniu - jeśli sa biskupami albo duchownymi, należy ich wykluczyć: biskupów z episkopatu, duchownych ze stanu duchownego, a jeśli sa mnichami lub osobami świeckimi, mają być wyłączeni ze społeczności wiernych" (Baron, Pietras 2002: 223, 225).

Tradycja chrześcijańska nie lekceważyła jednak do końca afirmatywnego aspektu, ukrytego w słowie herezja - możliwości świadomego i wolnego wyboru. Interesujący jest kontekst, w jakim to słowo występuje w Dziejach Apostolskich (Dz 24,14), gdzie stanowi część mowy Pawła z Tarsu do rzymskiego namiestnika Jerozolimy w obecności żydowskich oskarżycieli, którzy zarzucali mu sianie zamętu religijnego: „To jednak wyznaję przed tobą: według drogi, nazywanej przez nich sektą [hairesis], służę Bogu moich ojców, wierząc we wszystko, co napisane zostało w Prawie i u Proroków”. W tym fragmencie to właśnie chrześcijaństwo zostaje opisane jako „wybór” - a więc „herezja” względem wyznawców ortodoksyjnego judaizmu.

Również wśród teologów pojawiały się głosy zachęcające do czytania i analizowania ksiagg heretyckich. Najbardziej spektakularnym przykładem takiej postawy jest Jan Hus, który - zanim sam został spalony na stosie podczas soboru w Konstancji w 1415 roku - pisał: „Książki heretyckie należy czytać, a nie palić, ponieważ zdarza się, że znajduje się w nich prawda" (Evans 2003: XV). Cytat pochodzi z pracy Husa o możliwie najdosadniejszym retorycznie tytule $O$ potrzebie czytania ksiażek heretyckich (De libris haereticorum legendis). 


\section{/// Analiza}

W bieżącym numerze „Stanu Rzeczy” staraliśmy się zarówno przyjrzeć klasycznym kontekstom, w których występuje pojęcie herezji, jak i pokazać jego istniejące oraz możliwe reinterpretacje. Problem społecznych konsekwencji (nad)używania pojęcia herezji analizuje artykuł Moniki Strupiechowskiej Pojecie herezji jako narz̨dzie sprawowania władzy w dyskursie medialnym. Praca identyfikuje strategie aktorów życia społecznego, którzy posługują się pojęciem herezji w celu narzucenia władzy oponentom ideowym. Jak wskazuje autorka, decydujące znaczenie ma sam akt uznania czegoś za herezję, może się on dokonywać w oderwaniu od jakichkolwiek teologicznych i prawnokanonicznych analiz, na mocy samego aktu mowy. Strupiechowska zwraca uwagę na istotny aspekt wyrokowania o heretyckości - to nie tylko narzędzie umacniania władzy i pozycji społecznej przez instytucje kościelne i ich reprezentantów, ale także próba opierania się zmianie społecznej, nostalgiczna tęsknota za konserwatywną utopią.

Z podobnych narzędzi analitycznych - interpretacji dyskursu tygodników opiniotwórczych - korzysta Anna Dietl w artykule Ortodoksja i herezja w relacjach ludzi i zwierzat w narracji wybranych tygodnikón opiniotwórczych. Autorka decyduje się na analizę porównawczą dyskursów w trzech polskich czasopismach, reprezentujących zróżnicowane sympatie ideowe i zajmujących różne stanowiska wobec doktryny rzymskokatolickiej oraz wobec miejsca instytucji religijnych w państwie. Tekst prezentuje szerokie spektrum sposobów wykorzystywania pojęcia herezji do analizy żywo dyskutowanego problemu relacji ludzi i zwierząt. Dokonana przez autorkę identyfikacja „ortodoksji” i „herezji”" tego dyskursu, a więc metodyczne wykorzystanie pierwotnie religijnej ramy pojęciowej, pozwala lepiej zrozumieć zarówno samą dynamikę publicznej dyskusji, jak i powtarzające się w niej zabiegi odmawiania oponentom przynależności do rozmaitych wspólnot: czy to ludzi myślących, czy liberalnych demokratów, czy progresywnych Europejczyków, czy wreszcie spadkobierców chrześcijańskiej cywilizacji.

Szerszą panoramę ideową, w ramach której mieszczą się również analizowane w numerze dyskursy medialne, rysuje tekst Jonathana Scovila $W$ krainie Ulro. Religijne wyobrażenia o kosmosie i czlowieku wobec naukowego obrazu swiata. Autor omawia zasadniczy przedmiot sporu pomiędzy mieszczącymi się w chrześcijańskim horyzoncie światopoglądami religijnymi a „naukowym obrazem świata”, mającym swoje źródło jeszcze w dziewiętnastowiecznym scjentyzmie, następnie zaś spopularyzowanym i uznanym za zdroworozsądkowy. Tekst trafnie diagnozuje impas metafizycznej wy- 
obraźni, który w określonym momencie dotknął europejską tradycję intelektualną. Może stanowić także dobry punkt wyjścia do rozważań, co w tej sytuacji zmienia dziejąca się na naszych oczach katastrofa ekologiczna.

\section{/// Praktyka}

Zdecydowaliśmy, by niniejszy numer „Stanu Rzeczy” był także praktycznym ćwiczeniem $z$ herezji. Refleksja humanistyczna jest częścią toczącej się publicznie rozmowy. To starcie wizji, konceptów, ale też pozycji społecznych i doświadczeń. Sprzyja nie tylko powstawaniu nowych idei, lecz także pomaga ustalać warunki życia zbiorowego i uwzględniać w nim pominięte lub wykluczane punkty widzenia. Nieocenioną wartość ma tu literatura, która zdaniem Richarda Rorty'ego jest w istocie szerszą i nowocześniejszą kategorią mieszcząca w sobie i przekształcającą wcześniejsze uniwersalistyczne pragnienia religii i filozofii (Rorty 2009: 145-166). Literatura bowiem służy budowaniu demokracji i pomaga doskonalić wrażliwość.

Zamieściliśmy w tym numerze cztery wyzwania literackie: dwa zbiory wierszy, opowiadanie i esej. Obie kolekcje wierszy zostały napisane w języku czeskim i znakomicie przełożone na polski przez Zofię Bałdygę, poetkę i tłumaczkę najnowszej literatury czeskiej i słowackiej. Utwory Adama Borziča pochodzą z tomu Zachodnio-wschodnie lustra (Západo-východni zrcadla), w którym autor sięga niejednokrotnie po kluczowe postaci przednowożytnej tradycji arabskiej i europejskiej, przetwarzając istotne aspekty ich myśli lub sztuki w gęste przeżycia liryczne. Wrażliwości religijne, ale i całe uniwersa kulturowych obrazów, mieszaja się tu ze sobą niczym wpływy arabskich filozofów $\mathrm{z}$ arystotelizmem $\mathrm{w}$ pracach średniowiecznych scholastyków. Borzič stara się wykorzystywać orientalistyczną nostalgię, żywą w europejskim myśleniu, by zaraz potem dekonstruować uwodzące motywy klasyczne i tworzyć miejsce dla nowych, niepewnych siebie przeżyć późnej nowoczesności.

Wiersze Jana Škroba charakteryzują się zarówno inną dynamiką frazy, jak i odmiennym obrazowaniem. Ja liryczne jest raczej zafascynowanym ezoteryką uczniem Nietzschego niż myślicielem tęskniącym za perskimi dywanami. Chrześcijańskie toposy zostaja w tych utworach wykorzystane jako nośne metafory, umeblowanie europejskiej głowy, które sprawia, że nieprzyjaciołom przypisujemy religijną nadgorliwość faryzeuszy, a chwilę medytacyjnego namysłu nad światem możemy opisać jako chrystusa, który objawia się nam na mokradłach (pozbawiony jednak nieodzownej niegdyś wielkiej litery). 
Grę z imaginarium religijnych skojarzeń prowadzi również Jarek Westermark w opowiadaniu Precesja. Autor wiedzie nas po religijnych tropach, przez wydawałoby się zwyczajną rzeczywistość polskiego miasta średnich rozmiarów, aby stopniowo przesycać realistyczny obrazek magia, którą bez trudu tworzy wszechwładna autorska imaginacja. Westermark nie pozwala jednak czytelniczce i czytelnikowi rzucić się bez pamięci w świat literackiej fantazji, trzyma czytających w niepewności, czy mają do czynienia z cudem religijnym, czy ze złudzeniem psychicznym.

Esej Jarosława Skurzyńskiego Jak odkryłem, że wszystko jest tańcuszkiem szczéścia ma w sobie urok wstydliwego rachunku sumienia. Autor przekonująco pokazuje ludzką skłonność do porzucania racjonalnego myślenia w imię innych wartości, raz uznawanych za wyższe, innym razem skrywanych. Niekiedy zaś - jak w przypadku łańcuszków - nie chodzi nawet o wartości, ale o przedracjonalny, magiczny niepokój o konsekwencje przerwania łańcucha, złamania kręgu, nieprzyjęcia rzuconego nam wbrew naszej woli wyzwania. Cóż bowiem szkodzi posłać kolejnym dziesięciu osobom rozbudowaną wiadomość tekstowa, jeśli w zamian los może przez dłuższy czas spoglądać na nas samych życzliwie?

\section{/// Dyskusja}

Znacząca część numeru zajmują krytyczne omówienia książek i polemiki przez nie sprowokowane. Zaryzykuję tu banalność, przypominając, że to właśnie dzięki nim idee humanistyczne żyja, doskonala się i prowadzą do przeobrażenia rzeczywistości społecznej. Wnikliwa lektura jest przy tym największą wartością, jakiej życzyć mogą sobie autorki i autorzy posyłający drukiem w świat efekty swoich wielomiesięcznych lub wieloletnich badań.

Miłosz Puczydłowski omawia książkę Mateusza Pencuły Ateistycz̨na apologetyka religii, nie tylko wskazując na odkrycia, które przynosi przyjęta w pracy perspektywa badawcza, ale także stawiając pytanie o znaczenie przyjętej definicji wiary i jej doświadczenia dla filozoficznego ujęcia problemu ateizmu. Krzysztof T. Konecki recenzuje Ludowa historie Polski Adama Leszczyńskiego, wskazując na możliwe pożytki dla warsztatu badawczego socjologa, płynące z rzetelnego przemyślenia i inkorporowania metodologii przyjętej w książce. Tomasz Rakowski przygląda się pracy Cięcia. Mówiona historia transformacji Aleksandry Leyk i Joanny Wawrzyniak. Lektura Rakowskiego przebiega dwutorowo. Z jednej strony uwypukla zalety zupełnie nowego ujęcia historii transformacji: perspektywy głosów rozmówczyń i rozmówców z zastosowaniem niemal przezroczystej, upłynniającej jedy- 
nie tok wypowiedzi redakcji oraz dodaniem komentarza i analizy autorek. Z drugiej strony pokazuje prawdopodobne, kryjące się pod tekstem pisanym znaczenia i pola interpretacyjne, wypływające z zawahań, pauz, tonów przyjmowanych przez osoby mówiące, a niemożliwych do oddania w płynnej, narracyjnej transkrypcji. Wojciech Rafałowski skrupulatnie omawia książkę Adama Gendźwiłła Wybory lokalne w Polsce. Uczestnictwo, konkurencja i reprezentacja polityczna w demokracjach mniejszej skali. Recenzent zwraca szczególną uwagę na oryginalne i płodne w konkluzje podejście metodologiczne Gendźwiłła, który nie traktuje wyborów samorządowych jako „wyborów drugorzędnych", stanowiących jedynie próbną batalię dla krajowych partii politycznych przed wyborami parlamentarnymi czy prezydenckimi. Jak wskazuje Rafałowski, Gendźwiłł przekonująco argumentuje za samoistna wartością wyborów lokalnych i dzięki jej uznaniu dostrzega te ich aspekty, które wymykają się partyjnej, ogólnopolskiej perspektywie.

Ponadto w numerze Michał Pospiszyl reaguje na recenzję Adama Lipszyca, wchodząc w spór o znaczenie kategorii „ruiny” w myśleniu Waltera Benjamina, a zarazem o możliwe interpretacje jego metody filozoficznej. Paweł Rojek zaś żegna zmarłego profesora Andrzeja Walickiego, wybitnego badacza nowożytnej myśli rosyjskiej oraz polskiej, wieloletniego członka rady naukowej „Stanu Rzeczy”. Publikujemy także fragmenty istotnego, choć zapomnianego tekstu Jewgienija Nikołajewicza Trubeckiego, poświęconego rozwojowi doktryny Augustyna z Hippony, w przekładzie i z komentarzem niżej podpisanego.

Zapraszamy do zanurzenia się w gąszczu tekstów, komentarzy i polemik, do spojrzenia na nie jak na wielonurtową rozmowę. A także do odnalezienia wśród nich własnych haeiresom - rzeczy wybranych.

Bibliografia:

/// Baron A., Pietras H., red. 2002. Dokumenty soborón powszechnych, t. I, WAM.

/// Evans G.R. 2003. A Brief History of Heresy, Blackwell.

/// Kołakowski L. 2010, Herezja, Znak.

/// Rorty R. 2009. Filorofia jako polityka kulturalna, tłum. B. Baran, Czytelnik. 
/// Michał Rogalski - filozof, tłumacz, dramatopisarz i reżyser teatralny. Jest autorem książki Producenci margaryny? Marian Zdziechonski i polski modernizm katolicki (Universitas 2018) poświęconej reformatorskim nurtom myślowym w polskim katolicyzmie na przełomie XIX i XX wieku. Jego zainteresowania badawcze obejmują historię myśli katolickiej w późnej nowożytności oraz filozoficzne aspekty światopoglądów religijnych.

ORCID: https://orcid.org/0000-0001-8225-7026

E-mail: michal.f.rogalski@gmail.com 